\title{
Human Papillomavirus-Related Squamous Cell Carcinoma of the Penis
}

National Cancer Institute

\section{Source}

National Cancer Institute. Human Papillomavirus-Related Squamous Cell Carcinoma of

the Penis. NCI Thesaurus. Code C27682.

A squamous cell carcinoma that arises from the penis and is caused by human papillomavirus infection. 